\title{
Pengaruh Penerapan Media Video Terhadap Kreativitas Belajar Siswa Kelas III Pada Mata Pelajaran Sejarah Kebudayaan Islam (SKI) Di Madrasah Ibtidaiyah Quraniah 8 Palembang
}

Ines Tasya Jadidah

MIN 1 Teladan Palembang

jadidahines@gmail.com

Amir Hamzah

Fakultas Ilmu Tarbiyah dan Keguruan UIN Raden Fatah

Amirhamzah_uin@radenfatah.ac.id

\begin{abstract}
ABSTRAK
Pelajaran Sejarah Kebudayaan Islam merupakan salah satu pelajaran yang dianggap oleh siswa atau guru sebagai materi hafalan saja sehingga proses pembelajaran sangat menjenuhkan. Hal ini mengakibatkan pembelajaran kurang menarik perhatian peserta didik dan terkesan hanya untuk menyelesaikan pokok bahasan saja. Agar hal ini tidak berlarut - larut dan berkepanjangan maka kiranya seorang guru harus meningkatkan keterampilan dalam mengajar. Salah satunya adalah dengan pemilihan dan penggunaan metode dan media yang tepat sehingga siswa dapat tertarik dengan mata pelajaran Sejarah Kebudayaan Islam

Penelitian ini dilakukan di Madrasah Ibtidaiyah Quraniah 8 Palembang. Untuk mengetahui adakah pengaruh yang signifikan penerapan media video terhadap kreativitas belajar siswa kelas III mata pelajaran SKI di Madrasah Ibtidaiyah Quraniah 8 Palembang. Jenis penelitian ini merupakan jenis penelitian eksperimen menggunakan penelitian eksperimen Pre-experimental design (non design) bentuk one-group pretest-posttest design. Populasi adalah seluruh siswa Madrasah Ibtidaiyah Quraniah 8 Palembang yang berjumlah 352 siswa yang terdiri dari laki-laki berjumlah 153 siswa dan perempuan berjumlah 199 siswa. Sampel adalah sebagian atau wakil populasi yang diteliti. Sampel dalam penelitian ini adalah seluruh siswa kelas III A jumlahnya 29 siswa Madrasah Ibtidaiyah Quraniah 8 Palembang. Teknik pengumpulan data yang digunakan dalam penelitian ini adalah dengan observasi, wawancara, angket, dan dokumentasi. Analisis data untuk mengambil kesimpulan menggunakan rumus test $\mathrm{t}$.

Hasil analisis data dapat diinterpretasikan bahwa kreativitas belajar siswa pada kelas posttest mengalami peningkatan skor mean jika dibandingkan dengan pretest yaitu yaitu 66,48 (pretest) meningkat menjadi 80,48 (posttest). Kemudian setelah dilakukan hipotesis dengan rumus uji t maka, ternyata didapat to $=5,39$, dengan df sebesar 28 itu diperoleh besarnya $t$ yang tercantum pada tabel nilai $\mathrm{t}\left(\mathrm{t}_{\mathrm{t} . \mathrm{ts} 5 \%}\right.$ $=2,05$ dan $\left.\mathrm{t}_{\mathrm{t} \text {.ts } 1 \%}=2,76\right)$ maka dapat diketahui bahwa $\mathrm{t}_{\mathrm{o}}$ lebih besar dari pada $\mathrm{t}_{\mathrm{t}}$ yaitu: $(2,05<5,39>2,76)$. Jadi, karena $t_{0}$ lebih besar daripada $t_{t}$ maka hipotesa nihil yang
\end{abstract}


diajukan ditolak, ini berarti bahwa ada pengaruh penerapan media video terhadap kreativitas belajar siswa.

Kata kunci: Media Video, Kreativitas Belajar, Mata Pelajaran Sejarah Kebudayaan Islam (SKI) Materi Kelahiran Nabi Muhammad SAW

\section{A. PENDAHULUAN}

Pendidikan merupakan suatu usaha membina dan mengembangkan aspekaspek rohaniah dan jasmaniah. Proses yang digunakan dalam usaha kependidikan adalah proses yang terarah dan bertujuan, yaitu mengarahkan anak didik kepada titik optimal kemampuannya. Tujuan yang hendak dicapai adalah terbentuknya kepribadian yang bulat dan utuh sebagai manusia individual, sosial dan hamba Tuhan yang mengabdikan diri kepadaNya. (Khoiron Rosyadi, 2004: 135)

Didalam ayat Al qur'an telah dijelaskan mengenai pentingnya penggunaan media bagi kehidupan terdapat dalam surat Al Alaq ayat 1-5 :

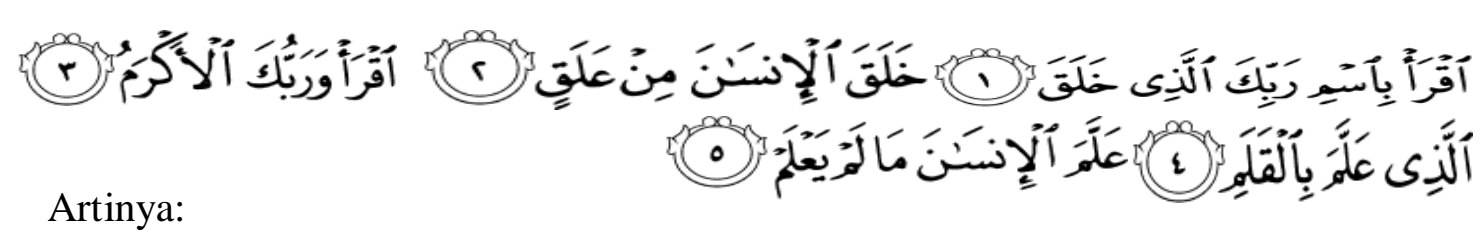

"Bacalah dengan (menyebut) nama Tuhanmu Yang menciptakan, Dia telah menciptakan manusia dari segumpal darah. Bacalah, dan Tuhanmulah Yang Maha Pemurah, Yang mengajar (manusia) dengan perantaraan kalam. Dia mengajarkan kepada manusia apa yang tidak diketahuinya." (Q.S Al Alaq: 1-5). (At- Tanzil, 2008: 1347)

Menurut Hujair, mengartikan video dengan: 1) bagian yang memancarkan gambar pada pesawat televisi, 2) rekaman gambar hidup untuk ditayangkan pada pesawat televisi. Jadi dia memaknainya dengan sesuatu yang berkenaan dengan penerimaan dan pemancaran gambar. (Sanaky Hujair AH, 2009: 106)

Pengertian video menurut berbagai sumber yang termasuk yaitu Video berasal dari media audio-visual yang menampilkn gerak yang disajikan dalam bentuk fakta pada suatu kejadian atau peristiwa. (Sadiman S Arief dkk., 2008: 74) Agar proses belajar mengajar dapat berhasil dengan baik, siswa sebaiknya diajak untuk memanfaatkan semua alat inderanya. Guru berupaya menampilkan rangsangan (stimulus) yang dapat diproses dengan berbagai indera. Semakin banyak indera yang digunakan untuk menerima dan mengolah informasi semakin besar kemungkinan 
informasi itu dimengerti dan dapat di pertahankan dalam ingatan. Belajar dengan menggunakan indera ganda ( pandang dan dengar ) akan memberikan keuntungan bagi siswa. Siswa akan belajar lebih banyak dari pada jika materi pelajaran disajikan hanya dengan stimulus pandang atau hanya dengan stimulus dengar. (Azhar Arsyad, 2012: 8-9)

Berdasarkan wawancara yang dilakukan peneliti dengan guru kelas III A di MI Quraniah 8 Palembang dengan ibu Rohimah (2014), didapat data bahwa terdapat beberapa permasalahan yang beliau hadapi khususnya dalam kegiatan pembelajaran, siswa tampak bosan dengan sajian materi yang mungkin kurang menarik, atau mungkin pula karena media pembelajaran yang tidak memadai.

Berdasarkan masalah tersebut, hambatan yang terjadi dalam proses pembelajaran yaitu berhubungan dengan sajian materi yang kurang menarik dan penggunaan media pembelajaran yang kurang mendukung. Sehubungan dengan itu maka perlu adanya upaya untuk menggunakan media pembelajaran yang tepat, bervariasi dan menarik. Salah satu media yang dapat menarik perhatian siswa yaitu media video, karena media video menyajikan pembelajaran yang akan diterima siswa melalui penglihatan dan pendengaran.

Sehubungan fenomena yang terjadi seperti penjabaran diatas, yang kemudian memacu rasa ingin tahu penulis untuk meneliti secara langsung keadaan dilapangan seperti apa dan kemudian penulis menetapkan judul penelitian ini sebagai judul skripsi yaitu "Pengaruh Penerapan Media Video Terhadap Kreativitas Belajar Siswa Kelas III Pada Mata Pelajaran Sejarah Kebudayaan Islam (SKI) di Madrasah Ibtidaiyah Quraniah 8 Palembang"

\section{B. KERANGKA TEORI}

Dalam kamus bahasa indonesia video adalah rekaman gambar hidup atau program televisi untuk ditayangkan lewat pesawat televisi. (Tri Rama, 1995)

Menurut Zubaidah, guru-guru bisa melakukan penyesuaian dan meningkatkan daya kreativitas dalam proses penyampaian isi-isi pengajaran supaya menjadi lebih berkesan dan mudah seiring dengan citarasa dan karakteristik pelajar. Video bersifat interaktif tutorial membimbing peserta didik untuk memahami sebuah materi melalui visualisasi. Peserta didik dapat secara interaktif mengikuti kegiatan praktik sesuai dengan yang diajarkan dalam video. (Eny Zubaidah, 1997: 62)

kreativitas adalah kemampuan yang mencerminkan kelancaran, keluesan dan orisinalitas dalam berpikir serta kemampuan untuk mengkolaborasi suatu gagasan. (Suryadi, 2007: 126) Pada hakikatnya kreativitas itu memiliki enam bagian utama 
yaitu kreativitas sebagai sebuah bentuk pembelajaran, representasi, produktifitas, originalitas, berfikir dengan kreatif atau penyelesaian masalah, dan alam semesta/alam ciptaan. (Florence Beetlestone, 2012: 2)

Mata pelajaran Sejarah Kebudayaaan Islam adalah mata pelajaran yang diajarkan di Sekolah Dasar dengan sebutan Tarikh Islam, sedangkan dalam Madrasah Ibtidaiyah disebut Sejaah kebudayaan Islam, Tarikh Islam atau sejarah kebudayaan islam merupakan pelajaran yang mempelajari tentang kisah-kisah nabi dan tokohtokoh islam yang diajarkan di SD/MI. (Departemen Agama RI, 2006: 12)

\section{MI Quraniah 8 Palembang}

Profil Sekolah

1. Nama Sekolah

2. Alamat

3. Status MI

4. Waktu Belajar

5. Kurikulum yang dipakai : KTSP

6. Jenjang Akreditasi : Terakreditasi

7. Nama Kepala Sekolah : Hotifa, S.Pd.I

8. Pendidikan Terakhir : S1

\section{HASIL PENELITIAN}

\section{Pengaruh Penerapan Media Video Terhadap Kreativitas Belajar Siswa Kelas III pada Mata Pelajaran SKI di MI Quraniah 8 Palembang}

\section{a. Data Tes}

Peneliti memberikan tes yang berbentuk angket pilihan ganda sebanyak 10 butir angket. Adapun butir- butir angket pada kelas pretest dan posttest disamakan. Untuk memberikan skor hasil jawaban angket siswa pada setiap butir angket terlebih dahulu peneliti membuat bobot penskoran atau acuan penskoran. Bobot skor dari seluruh angket jika jawaban sangat mudah maka mendapat skor 5 .

Adapun pemberian skor hasil angket siswa pada setiap butir angket terlebih dahulu peneliti membuat acuan penskoran. Skor tertinggi adalah 100 dengan kriteria jawaban mereka "sangat mudah" dan skor terendah adalah 20 dengan kriteria jawaban "sangat sulit". Pengambilan data ini dilaksanakan di Madrasah Ibtidaiyah Quraniah 8 Palembang yang dilakukan pada tanggal 2 februari dan 9 Februari 2015. Adapun sampel dalam penelitian ini terdiri dari 1 kelas yaitu kelas III A berjumlah 29 siswa. 
a) Hasil Pretest

Tabel 3

Distribusi Frekuensi Hasil Pretest Kreativitas Belajar Siswa Madrasah Ibtidaiyah Quraniah 8 Palembang Sebelum Diterapkan Media Video sebelum tindakan pada mata pelajaran Sejarah Kebudayaan Islam

\begin{tabular}{|c|c|c|}
\hline No & Nilai Tes & Frekuensi \\
\hline 1 & 80 & 2 \\
\hline 2 & 76 & 3 \\
\hline 3 & 72 & 4 \\
\hline 4 & 68 & 4 \\
\hline 5 & 64 & 8 \\
\hline 6 & 60 & 5 \\
\hline 7 & 56 & 3 \\
\hline & Jumlah & $\mathrm{N}=29$ \\
\hline
\end{tabular}

Dari hasil angket yang disebarkan pada siswa, didapat data tentang kreativitas belajar siswa sebelum diterapkan pembelajaran menggunakan media video. Setelah data-data terkumpul, maka proses pengelolaan data dilakukan sebagai berikut :

1) Peneliti melakukan penskoran ke dalam tabel frekuensi

$\begin{array}{llllllllll}76 & 64 & 64 & 72 & 80 & 64 & 72 & 64 & 72 & 64 \\ 60 & 64 & 60 & 80 & 60 & 76 & 64 & 60 & 68 & 64 \\ 60 & 76 & 56 & 56 & 68 & 56 & 68 & 68 & 72 & \end{array}$




\section{Tabel 4}

\section{Distribusi Kreativitas Belajar Siswa Sebelum Diterapkan Media Video di Madrasah Ibtidaiyah Quraniah 8 Palembang.}

\begin{tabular}{|c|c|c|c|c|c|c|}
\hline No & $\mathrm{X}$ & $\mathrm{F}$ & $\mathrm{Fx}$ & $\begin{array}{c}\mathrm{X} \\
(\mathrm{X}- \\
\left.\mathrm{M}_{\mathrm{x}}\right)\end{array}$ & $\mathrm{x}^{2}$ & $\mathrm{fx}^{2}$ \\
\hline 1 & 80 & 2 & 160 & 13.52 & 182.72 & 365.43 \\
\hline 2 & 76 & 3 & 228 & 9.52 & 90.58 & 271.73 \\
\hline 3 & 72 & 4 & 288 & 5.52 & 30.44 & 121.76 \\
\hline 4 & 68 & 4 & 272 & 1.52 & 2.30 & 9.21 \\
\hline 5 & 64 & 8 & 512 & -2.48 & 6.16 & 49.31 \\
\hline 6 & 60 & 5 & 300 & -6.48 & 42.03 & 210.13 \\
\hline 7 & 56 & 3 & 168 & -10.48 & 109.89 & 329.66 \\
\hline & Total & $\mathrm{N}=29$ & $\sum f x=1928$ & & & $\sum f^{2}=1357.24$ \\
\hline
\end{tabular}

2) Mencari nilai rata-rata

$\mathrm{M}_{\mathrm{x}}=\frac{\sum f x}{N}=\frac{1928}{29}=66.48$ dibulatkan 67

3) Mencari $\mathrm{SD}_{1}$

$\mathrm{SD}_{\mathrm{x}}=\sqrt{\frac{\sum f x^{2}}{N}}=\frac{1357.2}{29}=\sqrt{46.80}=6.8$ dibulatkan 7

4) Mengelompokkan kreativitas belajar siswa ke dalam tiga kelompok yaitu tinggi, sedang, rendah (TSR)

$$
\begin{array}{ll}
\frac{\mathrm{M}+1 \mathrm{SD}}{\mathrm{Nilai} \mathrm{M}-1 \mathrm{SD} \text { s.d. } \mathrm{M}+1 \mathrm{SD}} & \begin{array}{l}
\text { Tinggi } \\
\text { Sedang }
\end{array} \\
\mathrm{M}-\mathrm{ISD} & \text { Rendah }
\end{array}
$$

Lebih lanjut perhitungan pengkategorian TSR dapat dilihat pada skala dibawah ini :

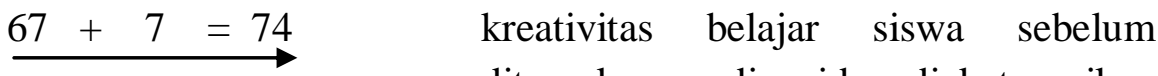

$$
\begin{aligned}
& \text { diterapkan media video di kategorikan } \\
& \text { tinggi } \\
& 60 \text { s.d. } 74 \\
& \text { kreativitas belajar sebelum diterapan } \\
& \text { media video di kategorikan sedang. } \\
& 67-7=60 \\
& \text { kreativitas siswa sebelum diterapkan } \\
& \text { media video dikategorikan rendah }
\end{aligned}
$$

Berdasarkan tabel diatas dapat diketahui kreativitas belajar siswa sebelum diterapkan media video yang tergolong tinggi (baik) sebanyak 5 orang $(17.2 \%)$, tergolong sedang sebanyak 16 orang siswa (55.2\%) dan yang tergolong rendah sebanyak 8 orang siswa (27.6\%). Dengan demikian 
kreativitas belajar siswa sebelum diterapkan media video di Madrasah Ibtidaiyah Quraniah 8 Palembang pada kategori sedang yakni sebanyak 16 orang $(55.2 \%)$ dari 29 siswa yang menjadi sampel penelitian ini.

b) Hasil Posttest

Tabel 6

\section{Distribusi Frekuensi Hasil Posttest Kreativitas Belajar Siswa}

\begin{tabular}{|c|c|c|}
\hline No & Nilai Tes & Frekuensi \\
\hline 1 & 94 & 1 \\
\hline 2 & 90 & 2 \\
\hline 3 & 88 & 4 \\
\hline 4 & 84 & 3 \\
\hline 5 & 80 & 9 \\
\hline 6 & 76 & 4 \\
\hline 7 & 72 & 6 \\
\hline & Jumlah & $\mathrm{N}=29$ \\
\hline
\end{tabular}

Dari hasil test yang disebarkan pada siswa, didapat data tentang kreativitas belajar siswa sesudah diterapkan media video. Setelah data-data terkumpul, maka proses pengelolaan data dilakukan sebagai berikut :

1) Peneliti melakukan penskoran kedalam tabel frekuensi

$\begin{array}{llllllllll}90 & 88 & 76 & 80 & 90 & 76 & 80 & 88 & 88 & 76 \\ 72 & 76 & 84 & 94 & 72 & 88 & 84 & 80 & 80 & 80 \\ 72 & 80 & 84 & 72 & 80 & 72 & 80 & 72 & 80 & \end{array}$

Tabel 7

Distribusi Kreativitas Belajar Siswa Sesudah Diterapkan Media Video di Madrasah Ibtidaiyah Quraniah 8 Palembang.

\begin{tabular}{|c|c|c|c|c|c|c|}
\hline No & $\mathrm{Y}$ & $\mathrm{F}$ & $\mathrm{Fy}$ & $\begin{array}{c}\mathrm{Y} \\
\left(\mathrm{Y}-\mathrm{M}_{\mathrm{y}}\right)\end{array}$ & $\mathrm{y}^{2}$ & $\mathrm{fy}^{2}$ \\
\hline 1 & 94 & 1 & 94 & 13.52 & 182.72 & 182.72 \\
\hline 2 & 90 & 2 & 180 & 9.52 & 90.58 & 181.16 \\
\hline 3 & 88 & 4 & 352 & 7.52 & 56.51 & 226.04 \\
\hline 4 & 84 & 3 & 252 & 3.52 & 12.37 & 37.11 \\
\hline 5 & 80 & 9 & 720 & -0.48 & 0.23 & 2.10 \\
\hline 6 & 76 & 4 & 304 & -4.48 & 20.10 & 80.38 \\
\hline 7 & 72 & 6 & 432 & -8.48 & 71.96 & 431.74 \\
\hline
\end{tabular}




\begin{tabular}{|c|c|c|c|c|c|}
\hline Total & $\mathrm{N}=29$ & 2334 & & & 1141.24 \\
\hline
\end{tabular}

1) Mencari nilai rata-rata

$\mathrm{M}_{\mathrm{y}}=\frac{\sum F Y}{N}=\frac{2334}{29}=80.48$ dibulatkan 81

2) Mencari $\mathrm{SD}_{1}$

$\mathrm{SD}_{\mathrm{y}}=\sqrt{\frac{\sum f y^{2}}{N}}=\sqrt{\frac{1141.24}{29}}=\sqrt{39.35}=6.27$ dibulatkan 7

3) Mengelompokkan perkembangan kreativitas belajar siswa ke dalam tiga kelompok yaitu tinggi, sedang, rendah (TSR)

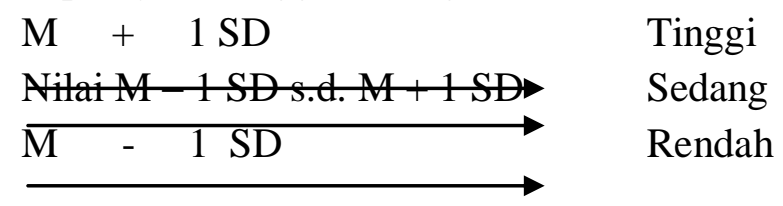

Lebih lanjut perhitungan pengkategorian TSR dapat dilihat pada skala dibawah ini :
$\stackrel{81+7 \stackrel{8}{\longrightarrow}}{\longrightarrow}$
kreativitas belajar siswa sesudah diterapkan media video di kategorikan tinggi

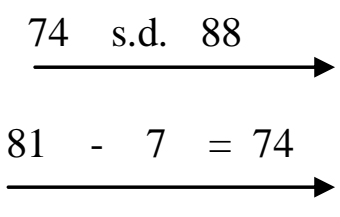
kreativitas belajar sesudah diterapan media video di kategorikan sedang.
kreativitas siswa seseudah diterapkan media video dikategorikan rendah

Berdasarkan tabel diatas dapat diketahui bahwa kreativitas belajar siswa sesudah diterapkan media video yang tergolong tinggi (baik) sebanyak 7 orang siswa (24.1\%), tergolong sedang sebanyak 16 orang siswa (55.2\%) dan yang tergolong rendah sebanyak 6 orang siswa (20.7\%). Dengan demikian kreativitas belajar siswa sesudah diterapkan media video pada siswa kelas III Madrasah Ibtidaiyah Quraniah 8 Palembang pada kategori sedang yakni sebanyak 16 orang siswa (55.2\%) dari 29 siswa yang menjadi sampel penelitian ini.

Dapat diinterpretasikan bahwa kreativitas belajar siswa pada kelas posttest mengalami peningkatan skor mean jika dibandingkan dengan pretest yaitu yaitu 66,48 (pretest) meningkat menjadi 80,48 (posttest).

\section{c) Analisis ada / tidak adanya pengaruh penerapan media video terhadap kreativitas belajar siswa kelas III}




\section{1) Hasil Uji Hipotesis}

Hipotesis dalam penelitian ini adalah ada atau tidak ada pengaruh penerapan media video terhadap kreativitas belajar siswa kelas III pada mata pelajaran sejarah kebudayaan Islam di Madrasah Ibtidaiyah Quraniah 8 Palembang materi kelahiran nabi Muhammad SAW. Dengan rumusan hipotesis sebagai berikut :

$\mathrm{H}_{\mathrm{a}}$ : Ada pengaruh yang signifikan penerapan media video terhadap kreativitas belajar siswa kelas III mata pelajaran SKI di Madrasah Ibtidaiyah Quraniah 8 Palembang.

Ho : Tidak ada pengaruh yang signifikan penerapan media video terhadap kreativitas belajar siswa kelas III mata pelajaran SKI di Madrasah Ibtidaiyah Quraniah 8 Palembang.

Uji Statistik tentang berhasil atau tidak media video pada mata pelajaran SKI di Madrasah Ibtidaiyah Quraniah 8 Palembang. Peneliti disini menggunakan uji statistik dengan rumus uji tes " $t$ " untuk mengetahui ada tidaknya pengaruh penerapan media video terhadap kreativitas belajar siswanpada mata pelajaran SKI kelas III di Madrasah Ibtidaiyah Quraniah 8 Palembang.

Uji Statistik dengan menggunakan rumus uji ' $t$ ”

$$
\mathrm{t}_{0}=\frac{M_{D}}{S E_{M_{D}}}
$$

Adapun langkah-langkah perhitungannya sebagai beriut :

1. Mencari D ( Difference = perbedaan) antar skor Variabel $\mathrm{X}$ dan skor Variabel $\mathrm{Y}$, maka $\mathrm{D}=\mathrm{X}-\mathrm{Y}$

2. Menjumlahkan $\mathrm{D}$, sehingga diperoleh $\sum D$

3. Mencari mean dari Difference, dengan rumus : $M_{D=\frac{\sum D}{N}}$

4. Mengkuadratkan D sehingga diperoleh $\sum D^{2}$

5. Mencari Deviasi Standar dari Difference $\left(\mathrm{SD}_{\mathrm{D}}\right)$

6. Mencari Standar Error dari Mean of Difference, yaitu $\mathrm{SE}_{\mathrm{MD}}$ dengan menggunakan rumus : $S E_{M_{D}}=\frac{S D_{D}}{\sqrt{N-1}}$

7. Mencari $\mathrm{t}_{0}$ dengan rumus : $\mathrm{t}_{0}=\frac{M_{D}}{S E_{M_{D}}}$

8. Memberikan interpretasi terhadap $\mathrm{t}_{0}$ dengan melakukan perbandingan antara $t_{0}$ dengan $t_{t}$, dengan patokan :

a. Jika $t_{0}$ lebih besar atau sama dengan $t_{t}$ maka Hipotesis Nihil ditolak; sebaliknya Hipotesa alternatif diterima atau disetujui. Berarti antara 
kedua variabel yang sedang kita selidiki perbedaannya, secara signifikan memang terdapat pengaruh.

b. Jika $t_{0}$ lebih kecil dari pada $t_{t}$ maka Hipotesa Nihil diterima; sebaliknya Hipotesa alternatif ditolak. Berarti bahwa perbedaan antara variabel 1 dan variabel II itu bukanlah perbedaan yang berarti, tidak terdapat pengaruh.

9. Menarik kesimpulan hasil penelitian

Dalam hubungan ini, dari sejumlah 29 orang siswa MI yang ditetapkan sebagai sampel penelitian, telah berhasil dihimpun data berupa skor hasil belajar mereka pada hasil pretest (sebelum diterapkannya media video) dan skor yang melambangkan perkembangan kreativitas belajar pada hasil posttest (sesudah diterapkan media video).

Tabel 9

\section{Perhitungan untuk Memperoleh t dalam Rangka Menguji}

Kebenaran / Kepalsuan Hipotesa

\begin{tabular}{|c|c|c|c|c|c|}
\hline \multirow{2}{*}{ No } & \multirow{2}{*}{ Nama Siswa } & \multicolumn{2}{|c|}{$\begin{array}{c}\text { Skor Kreativitas } \\
\text { Belajar Siswa }\end{array}$} & \multirow{2}{*}{$\mathrm{D}=(\mathrm{X}-\mathrm{Y})$} & $\mathrm{D}^{2}=(\mathrm{X}-\mathrm{Y})^{2}$ \\
\cline { 3 - 4 } & & $\begin{array}{c}\text { Pretest } \\
(\mathrm{X})\end{array}$ & $\begin{array}{c}\text { Posttest } \\
(\mathrm{Y})\end{array}$ & & \\
\hline 1 & Andre Perdana & 76 & 90 & -14 & 196 \\
\hline 2 & Aldi Pratama & 64 & 88 & -24 & 576 \\
\hline 3 & Astika Apriyani & 64 & 76 & -12 & 144 \\
\hline 4 & Anisa Zahara & 72 & 80 & -8 & 64 \\
\hline 5 & Ayu Sumarti N & 80 & 90 & -10 & 100 \\
\hline 6 & elsa Yuliani & 64 & 76 & -12 & 144 \\
\hline 7 & Halima Tusakdiah & 72 & 80 & -8 & 64 \\
\hline 8 & Khalisa Marliani & 64 & 88 & -24 & 576 \\
\hline 9 & lisa Anggraini & 72 & 88 & -16 & 256 \\
\hline 10 & Melisa Tri Mulia & 64 & 76 & -12 & 144 \\
\hline 11 & M. Aprilia S & 60 & 72 & -12 & 144 \\
\hline 12 & M. Deri A & 64 & 76 & -12 & 144 \\
\hline 13 & M. Abdullah f & 60 & 84 & -24 & 576 \\
\hline 14 & Nurul Hazizah & 80 & 94 & -14 & 196 \\
\hline 15 & Nur anisah A & 60 & 72 & -12 & 144 \\
\hline 16 & Nabilah & 76 & 88 & -12 & 144 \\
\hline 17 & Nia Wardana & 64 & 84 & -20 & 400 \\
\hline 18 & Nurul Azmi A & 60 & 80 & -20 & 400 \\
\hline 19 & Riska Apriyani & 68 & 80 & -12 & 144 \\
\hline
\end{tabular}




\begin{tabular}{|c|c|c|c|c|c|}
\hline 20 & Rizki Juniari & 64 & 80 & -16 & 256 \\
\hline 21 & Rangga Prasetya & 60 & 72 & -12 & 144 \\
\hline 22 & Raja Abadi & 76 & 80 & -4 & 16 \\
\hline 23 & Siti Mayang sari & 56 & 84 & -28 & 784 \\
\hline 24 & Tiara Dwi C & 56 & 72 & -16 & 256 \\
\hline 25 & Tri Kurnia Y & 68 & 80 & -12 & 144 \\
\hline 26 & Tasya Dwi S & 56 & 72 & -24 & 576 \\
\hline 27 & Zakia Salsabila & 68 & 80 & -12 & 144 \\
\hline 28 & Zahara R & 68 & 72 & -4 & 16 \\
\hline 29 & RA. Habibah & 72 & 80 & -8 & 64 \\
\hline & N $=29$ & 1928 & 2334 & $\sum D=414$ & $\sum D^{2}=5976$ \\
\hline
\end{tabular}

Dari tabel diatas telah berhasil diperoleh $\sum D=414$, dan $\sum D^{2}=5976$. Dengan di perolehnya $\sum D=414$, dan $\sum D^{2}=5976$ itu, maka dapat diketahui besarnya Deviasi Standar perbedaan skor antara variabel X dan variabel Y ( dalam hal ini $\left.\mathrm{SD}_{\mathrm{D}}\right)$ :

$$
\begin{gathered}
S D_{D}=\sqrt{\frac{\sum D^{2}}{N}-\frac{\left(\sum D\right)^{2}}{N}} \quad S D_{D}=\sqrt{\frac{5976}{29}-\frac{(414) 2}{29}} \\
S D_{D}=\sqrt{206,06-199,86} \quad S D_{D}=\sqrt{6,2}=S D_{D}=2,48
\end{gathered}
$$

Dengan diperolehnya $S D_{D}$ sebesar 2,48 mencari Standar Error mean variabel X dengan rumus :

$S E_{M_{D}}=\frac{S D_{D}}{\sqrt{N-1}}=\frac{2,48}{\sqrt{29-1}}=\frac{2,48}{5,29}=0,46$

Langkah berikutnya mencari harga $\mathrm{t}_{0}$ dengan menggunakan rumus :

$\mathrm{t}_{0}=\frac{M_{D}}{S E_{M_{D}}}$

$\mathrm{M}_{\mathrm{D}}$ telah diketahui yaitu 2,48, sedangkan $S E_{M_{D}}=0,46$ jadi,

$\mathrm{t}_{0}=\frac{2,48}{0,46}$

$\mathrm{t}_{0}=5,39$

Langkah berikutnya, diberikan interpretasi terhadap $t_{0}$ dengan terlebih dahulu memperhitungkan df dan db nya; df atau $\mathrm{db}=\mathrm{N}-1=29-1=28$. Dengan df sebesar 28 dikonsultasikan pada tabel " $t$ " baik pada taraf signifikansi 5\% maupun pada taraf signifikansi $1 \%$. 
Ternyata dengan df sebesar 28 itu diperoleh harga kritik $\mathrm{t}$ atau $\mathrm{t}_{\text {tabel }}$ pada taraf singnifikansi 5\% diperoleh sebesar 2,05 sedangkan pada signifikansi $1 \%$ diperoleh sebesari 2,76. dengan membandingkan besarnya t yang diperoleh dalam perhitungan $\left(t_{0}=5,39\right)$ dan besarnya $t$ yang tercantum pada tabel nilai $t\left(t_{t . t 5} \%=2,05\right.$ dan $t_{\text {t.ts } 1 \%}=$ 2,76) maka dapat diketahui bahwa $t_{\mathrm{o}}$ lebih besar dari pada $t_{\mathrm{t}}$ yaitu: $2,05<5,39>2,76$

Jadi, karena $t_{0}$ lebih besar daripada $t_{t}$ maka hipotesa nihil yang diajukan ditolak, ini berarti bahwa ada pengaruh penerapan media video terhadap kreativitas belajar siswa.

\section{E. KESIMPULAN}

Berdasarkan hasil penelitian dan pembahasan yang telah disajikan pada bab sebelumnya, maka dapat disimpulkan bahwa :

1. Penerapan media video terhadap kreativitas belajar siswa kelas III pada mata pelajaran SKI di Madrasah Ibtidaiyah Quraniah 8 Palembang tergolong baik.

2. Kreativitas belajar siswa sebelum diterapkan media video (pada pretest) memiliki rata-rata 66,48. sedangkan kreativitas belajar siswa sesudah diterapkan media video (pada posttest) memiliki rata-rata 80,48. .

3. Hasil uji hipotesis dengan membandingkan besarnya $t$ yang diperoleh didalam perhitungan $\left(\mathrm{t}_{0}=5,39\right)$ dan besarnya $\mathrm{t}$ yang tercantum pada tabel $\left(\mathrm{t}_{\mathrm{t}}\right.$ ${ }_{\text {ts }} 5 \%=2.05$ dan $t_{t}$ ts $\left.1 \%=2.76\right)$ maka dapat diketahui bahwa $t_{0}$ lebih besar dari $t_{t}$ yaitu $2,05<5,39>2,76$. Jadi dengan $t_{0}$ lebih besar daripada $t_{t}$ maka hipotesa nihil yang diajukan ditolak, ini berarti bahwa ada pengaruh penerapan media video dalam mengembangkan kreativitas belajar siswa.

\section{F. SARAN}

1. Penerapan media video penerapannya tidak membutuhkan biaya serta tidak membutuhkan waktu yang lama.

2. Dalam proses pembelajaran, disarankan kepada teman-teman yang akan melakukan penelitian ditempat yang sama atau tempat lain seperti saya harus memakai media pembelajaran yang tepat, sesuai dengan kondisi pembelajaran dilapangan.

3. Bagi semua pendidik dalam proses pembelajaran tidak hanya terampil dalam menerapkan teknik pembelajaran tetapi juga harus biasa mengetahui kondisi efektif proses pembelajaran. 


\section{Daftar Pustaka}

Arsyad, Azhar. 2011. Media Pembelajaran. Jakarta: Rajawali Pers.

At- Tanzil. 2008. Al-Qur'an dan Terjemahnya Juz 1 s/d 30 (Transliterasi), Bandung : Sinar Baru Algensindo.

Beetlestone, Florence. 2012. Creative Learning strategi pembelajaran untuk melesatkan kreativitas siswa. Bandung: Nusa Media.

Departemen Agama RI. 2006. Kurikulum Satuan Pendidikan/ KTSP SD/MI. Jakarta: CV.Timur Patra Mandiri.

Rama, Tri. 1995. Kamus Lengkap Bahasa Indonesia. Surabaya: Mitra Pelajar .

Rosyadi, Khoiron. 2004. Pendidikan Profektif. Yogyakarta: PustakaPelajar.

Sadiman, S Arief dkk. 2008. Media Pendidikan pengertian, penegembangann dan pemanfatannya. Jakarta: PT. Raja Grafindo Persada.

Sanaky, Hujar AH. 2009. Media Pembelajaran. Yogyakarta: Safiria Insania Press.

Smaldino, Sharon E, dkk. 2011. Instructional Technology And Media For Learning : Teknologi pembelajaran dan Media Untuk belajar. Jakarta: Kencana.

Suryadi. 2003. Cara Efektif Memahami Perilaku Anak Usia Dini. Jakarta: EDSA Mahkota. 